\title{
DYNAMIC SIMULATION AND COMPOSITION CONTROL IN A 10 L MIXING TANK
}

\author{
Yulius Deddy Hermawan") and Gogot Haryono \\ Chemical Engineering Department, Faculty of Industrial Technology, UPN “Veteran” Yogyakarta \\ Jl. SWK 104 (Lingkar Utara), Condongcatur, Yogyakarta \\ ${ }^{*}$ Corresponding author: ydhermawan@upnyk.ac.id
}

\begin{abstract}
The open loop experiment of composition dynamic in a 10 L mixing tank has been successfully done in laboratory. A $10 \mathrm{~L}$ tank was designed for mixing of water (as a stream-1) and salt solution (as a stream-2 with salt concentration, $c_{2}$ constant). An electric stirrer was employed to obtain uniform composition in tank. In order to keep the liquid volume constant, the system was designed overflow. In this work, 2 composition control configurations have been proposed; they are Alternative-1 and Alternative-2. For Alternative-1, the volumetric-rate of stream-1 was chosen as a manipulated variable, while the volumetric-rate of stream-2 was chosen as a manipulated variable for Alternative2. The composition control parameters for both alternatives have been tuned experimentally. The volumetric-rate of manipulated variable was changed based on step function. The outlet stream's composition response $\left(c_{3}\right)$ to a change in the input volumetric-rate has been investigated. This experiment gave Proportional Integral Derivative (PID) control parameters. The gain controllers $K_{c}$ $\left[\mathrm{cm}^{6} /(\mathrm{gr.sec})\right]$ for Alternative-1 and Alternative-2 are -34200 and 40459 respectively. Integral time constant $\left(\tau_{I}\right)$ and Derivative time constant $\left(\tau_{D}\right)$ for both alternatives are the same, i.e. $\tau_{I}=16$ second, and $\tau_{D}=4$ second. Furthermore, closed loop dynamic simulation using computer programming was also done to evaluate the resulted tuning parameters. The developed mathematical model of composition control system in a mixing tank was solved numerically. Such mathematical model was rigorously examined in Scilab software environment. The results showed that closed loop responses in PID control were faster than those in P and PI controls.
\end{abstract}

Keywords: closed loop; mixing tank; open loop; pid control; step function

\begin{abstract}
Abstrak
DINAMIKA SIMULASI DAN PENGENDALIAN KOMPOSISI DALAM TANGKI PENCAMPUR BERKAPASITAS 10 L. Percobaan loop terbuka dinamika komposisi dalam tangki pencampur $10 \mathrm{~L}$ telah dilaksanakan di laboratorium. Tangki $10 \mathrm{~L}$ dirancang untuk proses pencampuran air (sebagai arus-1) dan larutan garam (sebagai arus-2 dengan konsentrasi garam, $c_{2}$ konstan). Pengadukan diterapkan untuk mencapai keseragaman komposisi di dalam tangki. Untuk menjaga volume cairan di dalam tangki konstan, sistem dirancang overflow. Penelitian ini mengusulkan 2 konfigurasi pengendalian komposisi, yaitu Alternatif-1 dan Alternatif-2. Untuk Alternatif-1, laju alir volumetrik arus-1 dipilih sebagai variabel yang dimanipulasi $(M V)$, sedangkan arus-2 dipilih sebagai MV untuk Alternatif-2. Parameter-parameter pengendalian komposisi untuk kedua alternatif ditentukan melalui percobaan. Laju alir volumetrik dari MV diubah mengikuti fungsi tahap. Percobaan dilanjutkan dengan pengamatan respons komposisi keluaran tangki $\left(c_{3}\right)$ terhadap perubahan input fungsi tahap. Percobaan ini menghasilkan parameter pengendalian PID (Proportional Integral Derivative). Gain pengendali $K_{c}\left[\mathrm{~cm}^{6} /(\mathrm{gr.sec})\right]$ untuk Alternatif-1 and Alternatif-2 berturut-turut adalah -34200 dan 40459. Konstanta waktu integral $\left(\tau_{I}\right)$ dan konstanta waktu derivative $\left(\tau_{D}\right)$ untuk kedua alternatif adalah sama, yaitu $\tau_{I}=16$ detik, and $\tau_{D}=4$ detik. Kemudian, simulasi loop tertutup menggunakan pemrograman komputer dilaksanakan untuk mengevaluasi parameter pengendalian PID yang dihasilkan. Model matematika sistem pengendalian komposisi dalam tangki pencampur diselesaikan secara numerik dan diuji menggunakan software Scilab. Hasil simulasi menunjukkan bahwa respons loop tertutup pengendalian PID lebih cepat dibandingkan respons pengendalian $P$ dan PI.
\end{abstract}

Kata kunci: loop tertutup; tangki pencampur; loop terbuka; pengendalian pid; fungsi tahap 


\section{INTRODUCTION}

A mixing tank is frequently used in chemical process industries, for examples as a blending tank and/or a continuous stirred tank reactor. Liquid composition in a mixing tank is one of important parameters for mixing processes or chemical reaction processes in reactor. The propagation of mass disturbance is possibly occurred in mixing processes. Therefore composition control should be implemented to overcome the propagation of mass disturbances.

Composition control parameters such as proportional gain controller $\left(\mathrm{K}_{\mathrm{c}}\right)$, integral time constant $\left(\tau_{\mathrm{I}}\right)$, and derivative time constant $\left(\tau_{\mathrm{D}}\right)$ should be tuned properly, since they potentially affect the stability of mixing process. However, designed composition control system must be able to give a stable response in facing the mass disturbances. Therefore the study on the dynamic simulation and composition control is very important.

Some studies on process dynamic and control have been done previously. Recently, Hermawan et al. (2012) have presented the open loop composition dynamic in a $10 \mathrm{~L}$ Mixing Tank experimentally. Hermawan et al. (2010) have also presented the design of control configuration of non-interacting-tank system using quantitative analysis of relative gain array. Hermawan (2011) has implemented Process Reaction Curve (PRC) for tuning of temperature control parameters in a $10 \mathrm{~L}$ Stirred Tank Heater. Widayati and Hermawan (2007) have studied the mixing characteristic in a horizontal stirred tank.

The goals of this research were to propose the composition control configuration and to tune the composition control parameters (PID Control parameters) in a $10 \mathrm{~L}$ Mixing Tank. The resulted composition control parameters of proposed configurations were then examined through dynamic simulation. In order to achieve the aims of this research, this work was done in two parts, i.e. open loop experiment in the laboratory for tuning of composition control parameters and closed loop simulation using computer programming to explore dynamic behavior of the controlled system. The open loop experiment in the laboratory was carried out to tune composition control parameters. The volumetric rate of input stream was chosen as a manipulated variable to maintain the concentration of output stream at a constant value. In order to examine the control configuration, the mass disturbances were made based on step function. The Scilab software was utilized to carry out dynamic simulation.

\section{MATERIALS AND METHODS}

The experimental apparatus setup is shown in Figure 1. As can be seen in Figure 1, No.1 is a main tank that represents a mixing tank. This mixing tank has 2 input streams, i.e. stream- 1 and stream-2, and an output stream, i.e. stream-3. In normal condition, stream-1 and stream-2 come from the feeding tank No. 2 and No. 3, respectively. In this work, water was used as a stream-1 with its volumetric rate $f_{1}$ $\left[\mathrm{cm}^{3} / \mathrm{sec}\right]$, and salt solution as a stream-2 with its volumetric rate $f_{2}\left[\mathrm{~cm}^{3} / \mathrm{sec}\right]$ and concentration $c_{2}$ $\left[\mathrm{gr} / \mathrm{cm}^{3}\right]$. The input concentration $\mathrm{c}_{2}$ is constant. The output stream (stream-3) has volumetric rate $\mathrm{f}_{3}$ $\left[\mathrm{cm}^{3} / \mathrm{sec}\right]$ and concentration $\mathrm{c}_{3} \quad\left[\mathrm{gr} / \mathrm{cm}^{3}\right]$. The concentration $c_{3}$ is measured by means of Conductivity-meter. Since the liquid volume is kept constant, the system is designed overflow. A stirrer is employed to obtain uniform composition in the mixing tank. Tank No.4 was used if we want to make a concentration disturbance of stream-2. This disturbance could be made by changing the inlet concentration of stream- $2 c_{2}$ immediately. This is done by revolving the gate of three-way-valve (No. 7 in Figure 1), so that stream-2 comes from the tank No. 4 which is specifically prepared for making disturbance.

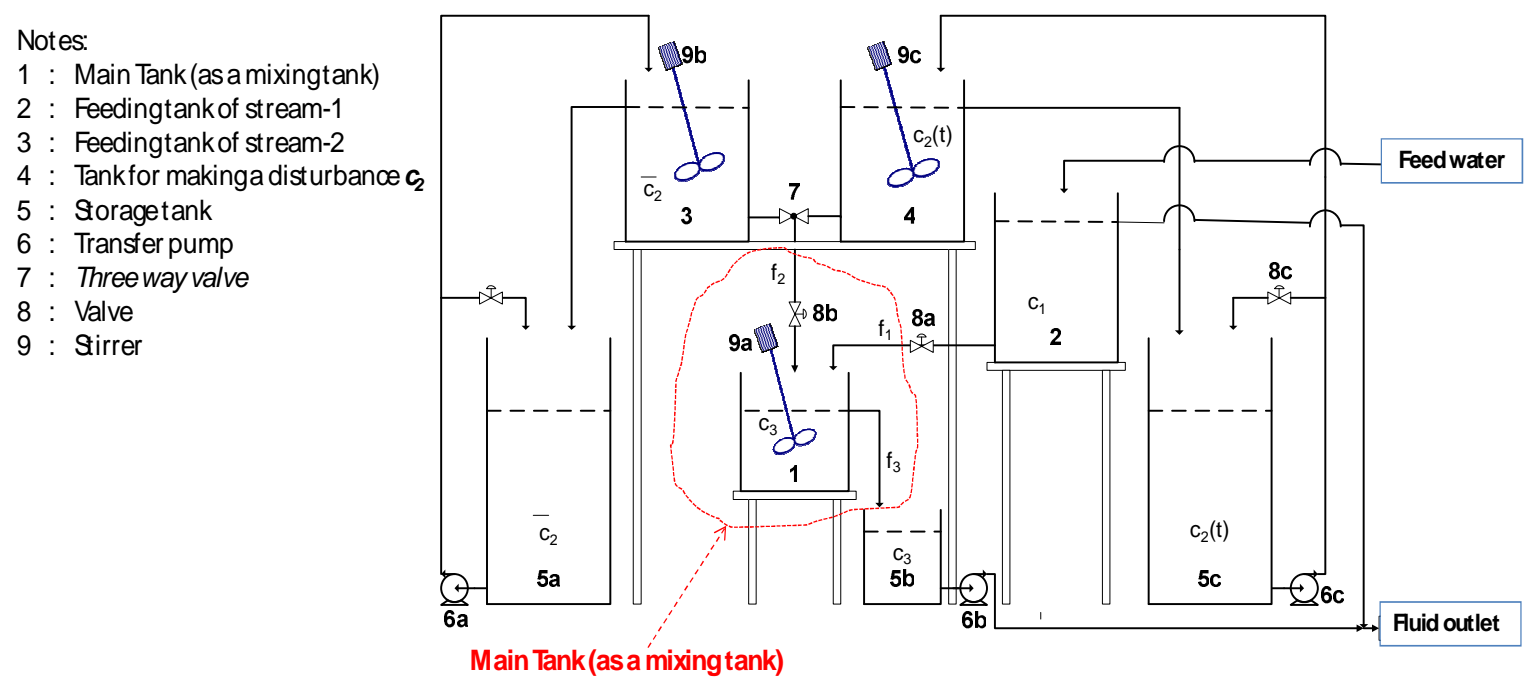

Figure 1. The experimental apparatus setup 
The material balance of the mixing tank can be written as follows:

$$
\frac{\mathrm{dc}_{3}(\mathrm{t})}{\mathrm{dt}}=\left[\mathrm{f}_{1}(\mathrm{t}) \overline{\mathrm{c}}_{1}+\mathrm{f}_{2}(\mathrm{t}) \overline{\mathrm{c}}_{2}-\left(\mathrm{f}_{1}(\mathrm{t})+\mathrm{f}_{2}(\mathrm{t})\right) \mathrm{c}_{3}(\mathrm{t})\right] / \mathrm{V}
$$

In this research, two composition control configurations are proposed, i.e. Alternative-1 and Alternative-2 as shown in Figure 2. Open loop tuning experiment is done for either alternatives by changing the opening valve of stream-1 (No. 8a in Figure 1) or stream-2 (No. 8b in Figure 1) to increase/decrease its volumetric rate immediately. The output concentration $\left(c_{3}\right)$ response to a change in input volumetric rate was then investigated. The resulted response will similar with that response given by first order plus dead time (FOPDT) model. PID Control parameters were then tuned by fitting the resulted FOPDT as proposed by Ziegler-Nichols (Smith and Corripio, 1997). These open loop experiments should be started from its initial (normal) conditions.

In order to evaluate the resulted PID Control parameters, dynamic simulation was carried out by means of a computer. A simple feedback control system was implemented to maintain liquid concentration in tank $\left(\mathrm{c}_{3}\right)$ constant by manipulating the volumetric rate of stream-1 or stream- 2 . Thus, the equation of manipulated variables for both of control configuration alternatives can be written as follow:

Alternative-1:

$$
\mathrm{f}_{1}(\mathrm{t})=\overline{\mathrm{f}}_{1}+\mathrm{K}_{\mathrm{c}} \mathrm{e}(\mathrm{t})+\frac{\mathrm{K}_{\mathrm{c}}}{\tau_{\mathrm{I}}} \int \mathrm{e}(\mathrm{t}) \mathrm{dt}+\mathrm{K}_{\mathrm{c}} \tau_{\mathrm{D}} \frac{\mathrm{de}(\mathrm{t})}{\mathrm{dt}}
$$

Alternative-2:

$$
\mathrm{f}_{2}(\mathrm{t})=\overline{\mathrm{f}}_{2}+\mathrm{K}_{\mathrm{c}} \mathrm{e}(\mathrm{t})+\frac{\mathrm{K}_{\mathrm{c}}}{\tau_{\mathrm{I}}} \int \mathrm{e}(\mathrm{t}) \mathrm{dt}+\mathrm{K}_{\mathrm{c}} \tau_{\mathrm{D}} \frac{\mathrm{de}(\mathrm{t})}{\mathrm{dt}}
$$

Where $e(t)$ is defined as:

$$
\mathrm{e}(\mathrm{t})=\mathrm{c}_{3}{ }^{\mathrm{SP}}-\mathrm{c}_{3}(\mathrm{t})=\text { error }
$$

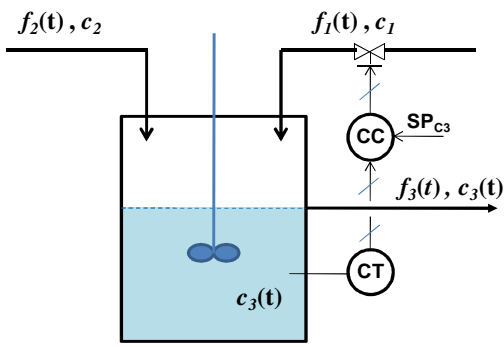

(a) Alternative-1
The developed mathematical model of composition control system in the mixing tank was solved numerically with the easiest way, that was Explicit Euler. The free software Scilab was chosen to carry out the closed loop dynamic simulation. The closed loop responses of composition control could then be explored in this work.

\section{RESULTS AND DISCUSSION}

Steady state parameters of the mixing tank are listed in Table 1. Based on steady state material balance, the process time constant is found to be 37 seconds (0.6 minutes). Therefore the system is considered quite sensitive to the changes of input disturbances.

\section{Tuning of Composition Control Parameters for Alternative-1}

For Alternative-1, volumetric rate of water $\left(f_{1}\right)$ is considered as a manipulated variable to maintain liquid composition in tank $\left(c_{3}\right)$. Figure 3.a shows the influence of $f_{1}$ on $c_{3}$. Volumetric rate of water decreases by an amount of $76 \mathrm{~cm}^{3} / \mathrm{sec}$ immediately; the concentration $c_{3}$ rises about $0.01 \mathrm{gr} / \mathrm{cm}^{3}$. The tuning results of composition control parameters $(\mathrm{P}$, PI, and PID) for Alternative- 1 are listed in Table 2.

\section{Tuning of Composition Control Parameters for Alternative-2}

For Alternative-2, volumetric rate of salt solution $\left(\mathrm{f}_{2}\right)$ is considered as a manipulated variable to maintain liquid composition in tank $\left(c_{3}\right)$. Figure 3.b shows the open loop composition response to a change in the volumetric rate $\mathrm{f}_{2}$. The concentration $\mathrm{c}_{3}$ increases (about $0.01 \mathrm{gr} / \mathrm{cm}^{3}$ ) as the volumetric rate $\mathrm{f}_{2}$ increases (about $70 \mathrm{~cm}^{3} / \mathrm{sec}$ ). The tuning results of composition control parameters (P, PI, and PID) for Alternative-2 are also listed in Table 2.

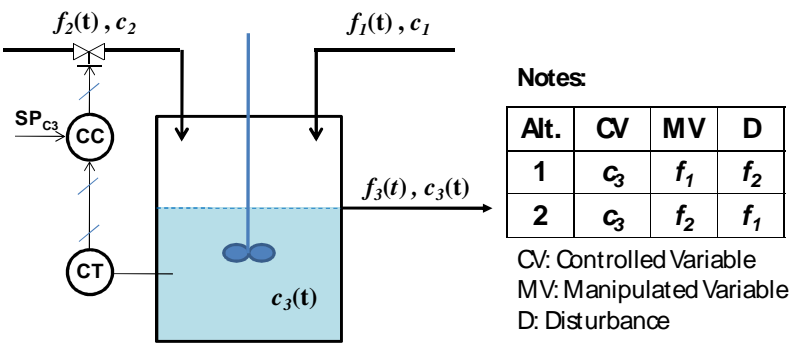

(b) Alternative-2

Figure 2. Composition Control Configuration: (a) Alternative-1, (b) Alternative-2.

Table 1. Steady state parameters

\begin{tabular}{ccc}
\hline No & Variable & Steady state \\
\hline 1 & Volumetric rate of stream- $1, f_{1}\left(\mathrm{~cm}^{3} / \mathrm{second}\right)$ & 106 \\
2 & Volumetric rate of stream- $2, f_{2}\left(\mathrm{~cm}^{3} / \mathrm{second}\right)$ & 71 \\
3 & Volumetric rate of stream-3, $f_{3}\left(\mathrm{~cm}^{3} / \mathrm{second}\right)$ & 177 \\
4 & Concentration of stream- $-1, c_{1}\left(\mathrm{gr} / \mathrm{cm}^{3}\right)$ & 0 \\
5 & Concentration of stream-2, $c_{2}\left(\mathrm{gr} / \mathrm{cm}^{3}\right)$ & 0.05 \\
6 & Concentration of stream-3, $c_{3}\left(\mathrm{gr} / \mathrm{cm}^{3}\right)$ & 0.0214 \\
7 & Liquid volume in tank, $V\left(\mathrm{~cm}^{3}\right)$ & 6600 \\
\hline
\end{tabular}


Table 2. Tuning results of composition control parameters

\begin{tabular}{|c|c|c|c|c|c|c|c|c|c|}
\hline \multirow{2}{*}{$\begin{array}{l}\text { Type of } \\
\text { Feedback } \\
\text { Control }\end{array}$} & \multicolumn{3}{|c|}{$\begin{array}{l}\text { Proportional Gain } \\
\text { Kc }\left[\mathrm{cm}^{6} /(\mathrm{gr} . \mathrm{sec})\right]\end{array}$} & \multicolumn{3}{|c|}{$\begin{array}{c}\text { Integral time } \\
\tau_{I}[\mathrm{sec}]\end{array}$} & \multicolumn{3}{|c|}{$\begin{array}{c}\text { Derivative time } \\
\tau_{D}[\mathrm{sec}]\end{array}$} \\
\hline & $\mathrm{Kc}$ & Alt-1 & Alt-2 & $\tau_{I}$ & Alt-1 & Alt-2 & $\tau_{D}$ & Alt-1 & Alt-2 \\
\hline$P$ & $\tau /\left(K . t_{D}\right)$ & -28500 & 33716 & - & - & - & - & - & - \\
\hline PI & $0.9 \tau /\left(K . t_{D}\right)$ & -25650 & 30344 & $3.3 \mathrm{t}_{\mathrm{D}}$ & 27 & 27 & - & - & - \\
\hline PID & $1.2 \tau /\left(K . t_{D}\right)$ & -34200 & 40459 & $2 t_{D}$ & 16 & 16 & $0.5 t_{D}$ & 4 & 4 \\
\hline
\end{tabular}
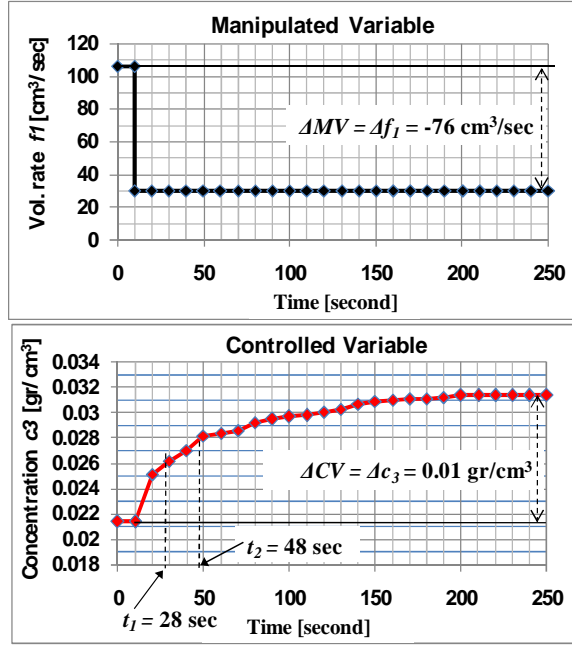

Zegler Nichols Fitting:

$0.283(\triangle \mathrm{CV}) \rightarrow t_{1}=28 \mathrm{sec}$

$0.632(\Delta \mathrm{CV}) \rightarrow t_{2}=48 \mathrm{sec}$

$\tau=\frac{3}{2}\left(t_{2}-t_{1}\right)=30 \mathrm{sec}$

$t_{D}=\left(t_{2}-\tau\right)-10=8 \mathrm{sec}$

$K=\frac{\Delta C V}{\Delta M V}=-1.32 E-4 \frac{\mathrm{gr} \cdot \mathrm{sec}}{\mathrm{cm}^{6}}$

(a) Alternative-1
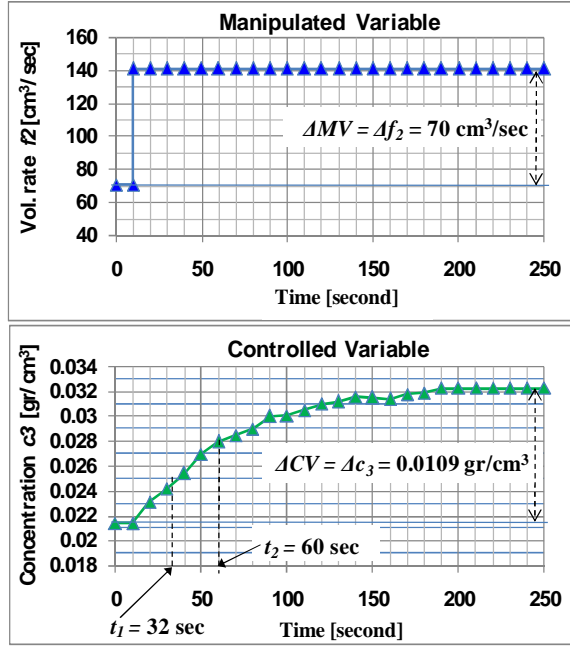

\section{Zegler Nichols Fitting:}

$0.283(\triangle \mathrm{CV}) \rightarrow t_{1}=32 \mathrm{sec}$

$0.632(\Delta C V) \rightarrow t_{2}=60 \mathrm{sec}$

$\tau=\frac{3}{2}\left(t_{2}-t_{1}\right)=42 \mathrm{sec}$

$t_{D}=\left(t_{2}-\tau\right)-10=8 \mathrm{sec}$

$K=\frac{\Delta C V}{\Delta M V}=1.56 E-4 \frac{\mathrm{gr} . \mathrm{sec}}{\mathrm{cm}^{6}}$

(b) Alternative-2

Figure 3. Tuning of Composition Control Parameters: (a) Alternative-1, (b) Alternative-2.

\section{Dynamic Simulation of Composition Control for Alternative-1}

Closed loop responses to a change in volumetric rate $\mathrm{f}_{2}$ are illustrated in Figure 4. The disturbances were made by following both functions of step increase and step decrease. For step increase's disturbance, volumetric rate $\mathrm{f}_{2}$ is increased by an amount of $70 \mathrm{~cm}^{3} / \mathrm{sec}$ at time equals 10 seconds. As can be seen, the composition controller (P, PI, and PID) attempts to return concentration $\mathrm{c}_{3}$ to its normal value of $0.0214 \mathrm{gr} / \mathrm{cm}^{3}$. P Control produces an offset of $0.0019 \mathrm{gr} / \mathrm{cm}^{3}$. Combination of proportional and integral control modes leads to eliminate an offset. Concentration $c_{3}$ can be returned to its set point by both of PI and PID Controls. Closed loop response of PID Control is fastest compared to P and PI Controls; Concentration $c_{3}$ can be returned to its set point at time equals 150 seconds.

For step decrease's disturbance, volumetric rate $\mathrm{f}_{2}$ is decreased by an amount of $56 \mathrm{~cm}^{3} / \mathrm{sec}$ at time equals 10 seconds. The concentration $c_{3}$ decreases first, and then rises to its normal value. However $\mathrm{P}$ Control still produces an off-set of about 0.0028 $\mathrm{gr} / \mathrm{cm}^{3}$. Closed loop response of PID Control is the fastest; the set point of $c_{3}$ can be achieved at time equals $120 \mathrm{sec}$.

Combination of the three control modes (PID control) gives a closed loop response which has in general the same qualitative dynamic characteristics as those resulting from PI control. To increase the speed of the closed loop response we can increase the value of proportional gain $\left(\mathrm{K}_{\mathrm{c}}\right)$ and/or decrease the value of integral time constant $\left(\tau_{\mathrm{I}}\right)$. But increasing $\mathrm{K}_{\mathrm{c}}$ and/or decreasing $\tau_{\mathrm{I}}$, the response become more oscillatory and may lead to instability. The introduction of the derivative mode brings a stabilizing effect to the system. Therefore, the derivative control action not only produces faster response but also produce more robust response. 

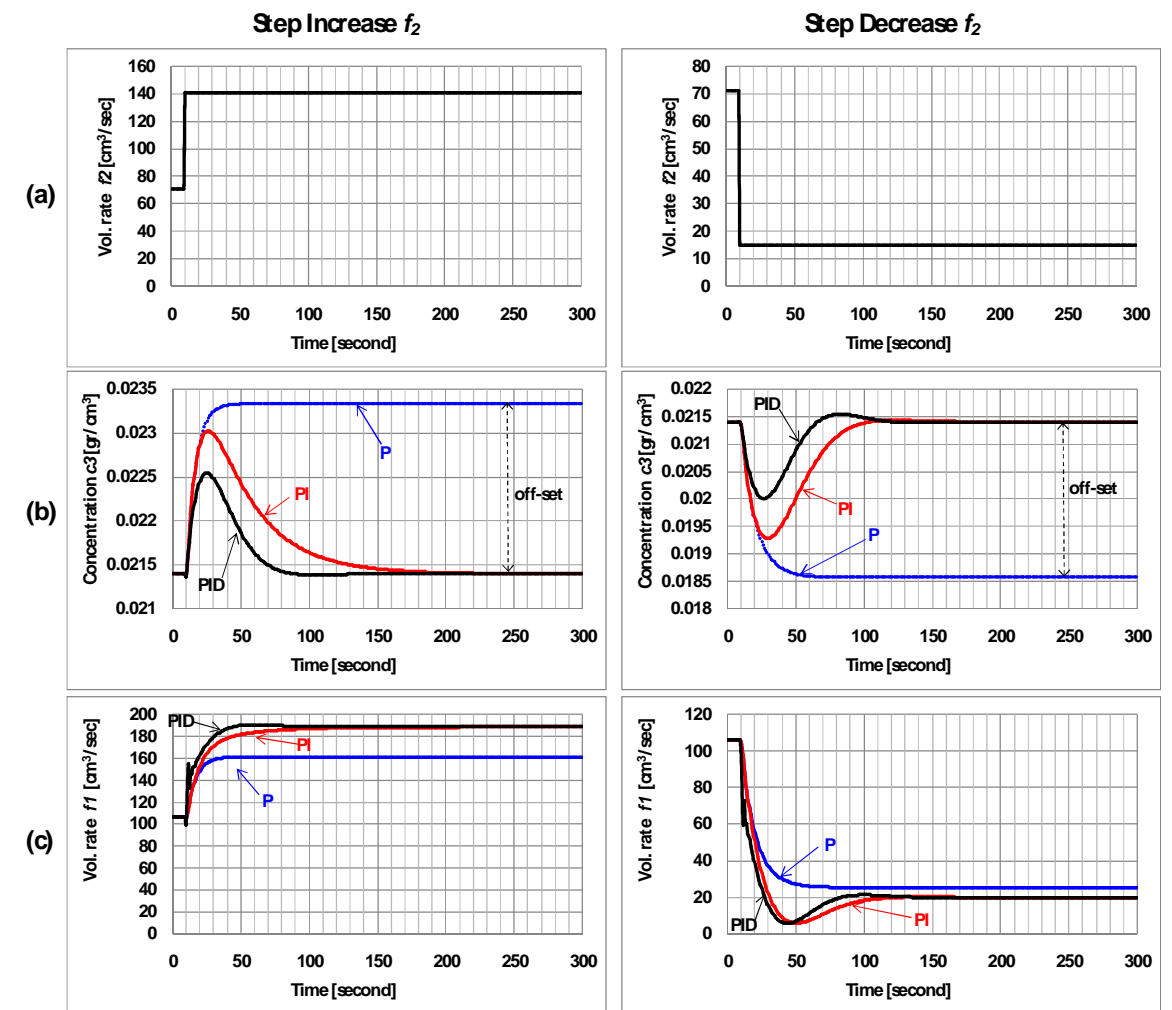

Figure 4. Closed Loop Responses of Composition Control Alternative-1 to a change in volumetric rate $f_{2}$ : (a) volumetric rate $\mathrm{f}_{2}$, (b) concentration $\mathrm{c}_{3}$, (c) volumetric rate $\mathrm{f}_{1}$
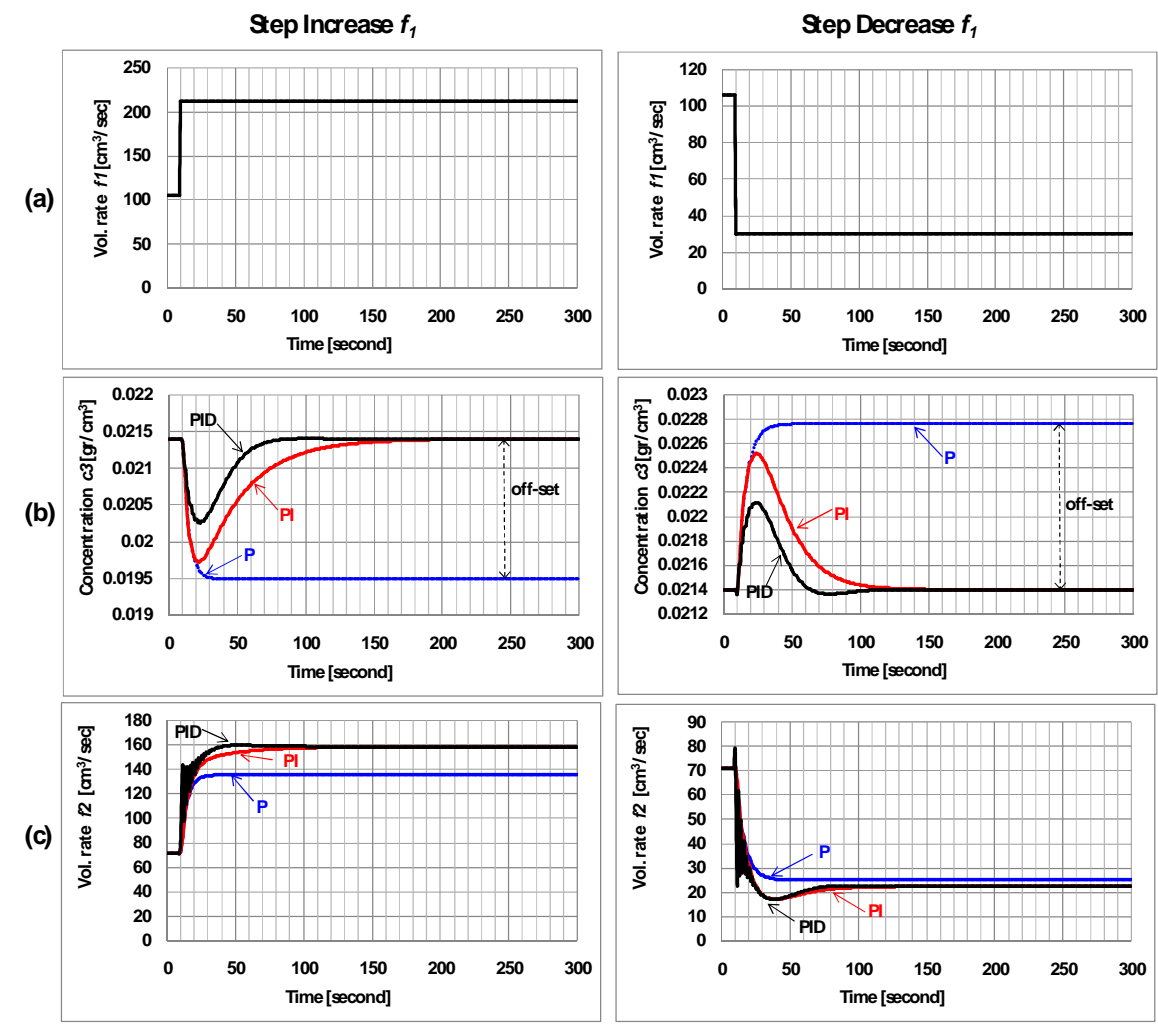

Figure 5. Closed Loop Responses of Composition Control Alternative-2 to a change in volumetric rate $f_{1}$ : (a) volumetric rate $\mathrm{f}_{1},(\mathrm{~b})$ concentration $\mathrm{c}_{3}$, (c) volumetric rate $\mathrm{f}_{2}$ 


\section{Dynamic Simulation of Composition Control for Alternative-2}

Figure 5 shows closed loop responses to a change in volumetric rate $f_{1}$. For this alternative, the disturbances were also made by following both functions of step increase and step decrease. For step increase's disturbance, volumetric rate $f_{1}$ is increased by an amount of $106 \mathrm{~cm}^{3} / \mathrm{sec}$ at time equals 10 seconds. As shown in Figure 5, concentration $c_{3}$ decreases as volumetric rate $f_{1}$ increases, and then concentration $c_{3}$ can be returned to its set point by both of PI and PID Controls. P Control produces an offset of $0.0019 \mathrm{gr} / \mathrm{cm}^{3}$. Closed loop response of PID Control is the fastest one; concentration $c_{3}$ can be returned to its set point at time equals 150 seconds.

For step decrease's disturbance, volumetric rate $f_{1}$ is decreased by an amount of $76 \mathrm{~cm}^{3} / \mathrm{sec}$ at time equals 10 seconds. The concentration $c_{3}$ increases as the volumetric rate of water decreases, and then drops to its normal value for PI and PID Controls. Again, P Control still produces an off-set of about 0.0014 $\mathrm{gr} / \mathrm{cm}^{3}$, and PID Control gives the fastest response.

\section{CONCLUSIONS}

This paper discussed tuning of composition control parameters and dynamic simulation in a $10 \mathrm{~L}$ mixing tank. Two alternatives of composition control configurations have been proposed. Closed loop dynamic behaviours of the two control configurations have also been explored. According to the dynamic simulation, the tuning results of composition control parameters produce stable responses. This research reveals that PID Composition Control produces the fastest responses compared to both of $\mathrm{P}$ and PI Composition Controls.

\section{ACKNOWLEDGEMENTS}

I appreciate the technical support on the use of free software SCILAB. I also thank Agustin, M. and Abia, H. for helping me during my research in laboratory.

\section{NOMENCLATURE}

$\triangle C V$ steady state change in controlled variable $\left[\mathrm{gr} / \mathrm{cm}^{3}\right]$

$\triangle M V$ step change in manipulated variable [ $\left.\mathrm{cm}^{3} / \mathrm{second}\right]$

$\tau \quad$ effective process time constant [second]

$\tau_{D} \quad$ derivative time constant [second]
$\tau_{I} \quad$ integral time constant [second]

$c_{1,2,3}$ concentration of stream $1,2,3\left[\mathrm{gr} / \mathrm{cm}^{3}\right]$

$c_{3}{ }^{S P}$ set point of liquid concentration in tank $\left[\mathrm{gr} / \mathrm{cm}^{3}\right]$

e $\quad$ error $\left[\mathrm{gr} / \mathrm{cm}^{3}\right]$

$f_{1,2,3} \quad$ volumetric rate of stream $1,2,3\left[\mathrm{~cm}^{3} /\right.$ second]

$K$ steady state gain of the process [(gr.second $) / \mathrm{cm}^{6}$ ]

$K_{c} \quad$ proportional gain controller [ $\mathrm{cm}^{6} /($ gr.second $\left.)\right]$

$t_{1} \quad$ time at which $c_{3}=0.283 \Delta c_{3 s}$ [second]

$t_{2} \quad$ time at which $c_{3}=0.632 \Delta c_{3 s}$ [second]

$t_{D} \quad$ effective process dead time [second]

$V \quad$ liquid volume in tank $\left[\mathrm{cm}^{3}\right]$

\section{REFERENCES}

Hermawan, Y.D., (2011), Implementation of Process Reaction Curve for Tuning of Temperature Control Parameters in A 10 L Stirred tank Heater, Journal of Materials Science and Engineering, Vol. 1, No. 4, September 2011, pp. 572-577.

Hermawan, Y.D., Haryono, G., Agustin, M. and Abiad, H., (2012), Composition Dynamic in A 10 L Mixing Tank, Seminar Nasional Teknik Kimia "Kejuangan" 2012, Department of Chemical Engineering, Faculty of Industrial Technology, UPN "Veteran" Yogyakarta, pp. C15-1-C15-6, (in Indonesian).

Hermawan, Y.D., Suksmono, Y., Narno Putra, R.M. and Puspitasari, M., (2010), Design of Process Control Configuration for Non-Interacting-Tank System using Quantitative Analysis of Relative Gain Array, Seminar Nasional Teknologi Simulasi (TEKNOSIM) 2010, Department of Industry and Mechanical Engineering, Faculty of Engineering, Gadjah Mada University, pp. 75-81, (in Indonesian).

Smith, C.A. and Corripio, A.B., (1997), Principles and Practice of Automatic Process Control, John Wiley \& Sons, $2^{\text {nd }}$ Ed., New York, pp. 303-367.

Widayati, T.W. and Hermawan, Y.D., (2007), Mixing Characteristic in A Horizontal Stirred Tank, Seminar Nasional Teknik Kimia "Kejuangan" 2007, Department of Chemical Engineering, Faculty of Industrial, UPN "Veteran" Yogyakarta, pp. B12-1B12-6, (in Indonesian). 